\title{
The lemniscate knowledge flow model
}

\author{
Paweł Weichbroth \\ Gdansk University of Technology \\ Faculty of Management and Economics \\ Department of Applied Informatics in Management \\ Narutowicza 11/12, 80-233 Gdańsk, Poland, \\ Email: pawel.weichbroth@hotmail.com
}

\author{
Kamil Brodnicki \\ Gdansk University of Technology \\ Faculty of Management and Economics \\ Department of Applied Informatics in Management \\ Narutowicza 11/12, 80-233 Gdansk, Poland, \\ Email: kamil.brodnicki@zie.pg.gda.pl
}

\begin{abstract}
Knowledge is seen as one of the main resources for organizations providing knowledge-intensive services. Therefore, sharing and reusing are the main goals of the modern knowledge management (KM) approach, driven by information and communication technologies (ICT). However, one must ask for the details in order to provide the means and tools to design and deploy an environment able to fulfil these two goals. We observed that the interactions occurring on knowledge resources can be reduced to a directional flow, and further described by distinguished internal phases. In our research we put forward two research questions: (1) what are the main entities in the knowledge flow supported by ICT? and (2) what are the main phases of the knowledge flow? In this paper we introduce the generic lemniscate knowledge flow model, which, grounded on recognized theory, learned principles and gathered practices, provides foundations to solve the above problem.
\end{abstract}

\section{INTRODUCTION}

$\mathrm{K}$ NOWLEDGE is a wide and abstract term, which has been the subject of epistemological discussion among western philosophers since times of ancient Greece. Since the second half of XX century, it has been widely studied in numerous research papers, reaching many definitions, contexts and phenomena and in the end, leading to a legitimate new scientific discipline, defined as knowledge management.

These days, people and machines produce countless volumes of data and information, consciously and intentionally transformed into knowledge. All of the aforementioned are important assets in knowledge-driven environments and the last is by far the most labour- and timeconsuming. In consequence, some employees spend the majority of their working hours in manual and highdemanding intellectual work, supported by computers processing and manipulating large amounts of data as an input, and producing information or even knowledge as an output $[1,2]$. As a result, a new concept of an employee was coined: a knowledge worker, whose job primarily involves the creation, distribution or application of knowledge [3]. By many, Peter Drucker is credited to be the first to use this term in his 1959 book, "Landmarks of Tomorrow".

Data sets encoded in a computer memory differ in format, size and type. In general use, there are two primary data formats: binary and text, and four primary data types: text, drawing, movie and voice. Ordered sequences of characters, images and spoken words are perceived as explicit and unique information objects. Here, we can point out objects that are in everyday use such as documents, presentations and spreadsheets, email-, voice- and video- messages, webblogs, forums, and pages. Each object processed and interpreted by an individual human mind, applicable and legitimate in a specified environment, where the consequences of an application are known or can be predicted, is considered to be a knowledge object. All of them, gathered and redacted, cleaned and re-processed, organized and integrated in one consistent repository, along with a user interface that facilitates SCRUD operations (an acronym for search, create, read and delete), constitute a unified system for knowledge workers. In present times, the most popular adjective in the research area "big" is naturally added when "big data" is involved and to underline the scale of the discussed problem (e.g. big management [4]). The ability to process massive data volumes entails other mandatory requirements against the system, such as efficient, fault-free and cost-effective. If we also take into account the human factor, the notion of the system is replaced by the environment to indicate additional performers and actions involved.

Now, we consider the problem of the design of an environment that will not only serve as pure technology but also provide interaction with other humans and available knowledge resources. We observed that the occurring interactions can be reduced to a directional flow, and further described by distinguished internal phases. In this context, we put forward two research questions: (1) what are the main entities? and (2) what are the main phases? Answers to these questions are embodied in the form of the generic lemniscate knowledge flow model and its detailed description, which, grounded on recognized theory, learned principles and gathered practices, provides foundations to solve the above problem.

The rest of the paper is organized as follows. The related work is presented in Section 2. In Section 3 we introduce the knowledge flow model. The research background is presented and referred to in Section 4. Final conclusions are included in Section 5. 


\section{RELATED WORK}

The recent interest in knowledge management, observed both in business and science, is nothing new. However, it is not a secret that nowadays, information and communication technologies are the basic means to efficiently support every phase of the KM process. For this reason, we only present the state of the art directly concerning knowledge management embedded in the context of ICT, as well as a general retrospection of its existence in the research areas of computer science and management.

Thinking in terms of computer science, our knowledge is materialized in so-called knowledge bases (KB) [5]. Bearing in mind the natural attributes of knowledge (e.g. aging, context, source) in order to fully illustrate the constraints and obstacles in the process of codifying, sharing and refining its resources, we should also point out other cons like: subjective burdens, mistakes, false assumptions, unreliable data mining techniques and methods or incomplete and imprecise data. Therefore, the necessity and urgency of knowledge verification and evaluation appear in the foreground in order to ensure its correctness, timeliness and objectiveness. This has been a subject of our previous and current research interests, generally focused on the area of knowledge management, where varied experiments have been performed on acquired resources from experts [6] or discovered frequent sets from web server log files [7].

In another work [8], we introduced the first multidimensional knowledge space model (including entityrelationship schema), implemented as a part of the developing system, designed to efficiently distribute and manage knowledge resources. We view our model as the foundation of a knowledge grid platform, where two significant aspects are considered: education- and researchdriven. Some aspects of applying an ontology in transforming and processing knowledge were widely discussed in [9], along with the related standards, terminology and languages; based on theoretical developments $[10,11,12]$, and managerial and organizational practice $[13,14,15]$; we also referred to the generic model of the knowledge life cycle and its internal phases, revisiting conditions, constraints and obstacles in the context of the knowledge grid assumptions.

Knowledge may be represented by a variety of forms. In [16] Kapłański et al. used a novel feature of the Ontorion system [17], that allows for describing knowledge and interacting with the user in semi-natural language [18], expressive enough to describe rich and complex things, groups of things, and relations between them. To present such capabilities, a stand-alone experiment was designed and executed. A software process simulation based on the multiagent approach was performed in order to imitate social behaviours in the software testing phase.

From the management panorama of the knowledge-based organization, Zack [19] distinguished four characteristics, summarized as a process, a place, a purpose and a perspective. A process consists of intra-organization activities engaged in the production of goods and delivery of services. A place includes the organization of boundaries in which knowledge is created, shared and refined. A purpose is defined by a mission and strategy which are considered in the frame of customer satisfaction. Finally, a perspective is related to beliefs, culture and religion, which may have an influence on decisions-makers. This abstract view of such an organization may be considered as a starting point for the analysis, design and organization of actors, tasks and resources, engaged in knowledge creation, sharing and evaluation [20].

The pure nature of the knowledge management process undoubtedly describes such values as: sincerity, impartiality and veracity. Mercier-Laurent et al. [21] classified sociocultural aspects as the most important in KM, which allow and empower knowledge creation and sharing. Besides this, the authors emphasize the role of the technical environment in the deliberate development and maintenance of key knowledge management processes and its influence on strategic management. In a similar way, Fazlagić et al. indicated the role of corporate portals (so-called intranets) in developing the processes of knowledge management, realized through a set of functions such as: internal services (concerning administration, finance and human resources), digital workspaces, unified communication facilities and document repositories [22].

To sum up and close this section, in the long-term, effective knowledge management may constitute a competitive advantage. Dominiak and Leja rhetorically ask "Does university need a strategy?" [23], and after an affirmative answer, later claim that in order to build, unfold and deploy a strategy, university ought to begin with a vision. To create a successful projection of the future, organization members should also directly embody all processes engaged in knowledge management in agreement and cooperation with all stakeholders. Generally speaking, the three main functions of management i.e. planning, organizing and controlling (the action-decision function will not be considered because it is commonly known) are intraand inter-related, penetrating and utilizing the available resources, where the most important are intellectual capital assets. Likewise, for business organizations, Teece [24] also argues that superior profits stem from intangible assets such as customer relationships, know-how and superior business processes.

\section{KNOWLEDGE FLOW MODEL}

Some believe in the sense of knowledge management and some do not. However, each organization to some extent, be it smaller or greater, utilizes knowledge in some way, intentionally or not. Nonetheless, we all must agree that the human memory, by nature, is imperfect because over time we unconsciously tend to rewrite some of its parts irrevocably or we are simply unable to retrieve them again. 
To bypass those limitations, nowadays knowledge is explicitly codified in a computer mass-storage memory, which lets us create solid backups and, what is the most important, retrieve and share knowledge on request at any time and in any place. On the other hand, the present-day environment is highly dynamic and productive, and as a consequence, knowledge ages rapidly. As an example, let us consider emerging financial and stock markets, legal regulations or even the solar system - indubitably, today we know something about them that may not be true anymore tomorrow.

In our methodical approach, firstly we specify the main goals, and secondly we design the process by determining particular phases in such a way that the sequence of their execution ultimately leads to satisfying each goal.

The main goals of knowledge management are to share knowledge with others, and to reuse it when necessary. From our point of view, the process itself consists of seven chronological phases where knowledge is (1) gathered, (2) codified, (3) shared, (4) verified, (5) enhanced (from the knowledge sender perspective), and (6) understood, (7) evaluated and shared again (from the knowledge recipient perspective). Such a directional knowledge flow occurs between three entities: knowledge sender (KS), machine and knowledge recipient (KR), where each of them plays a distinct role; however, direct or indirect interactions frequently occur between them. While KS and KR are both humans, the machine is an abstract term representing a set of information and communication technologies (ICT), generally referring to operating hardware (computers, networks and other physical devices) and software (applications, tools and systems). In this case, knowledge is a set of intangible assets, stored in a computer memory, represented by non-trivial plain-text or binary data structures. The underlying assumption, however, is not one based on viewing data as the raw material from which knowledge is created.

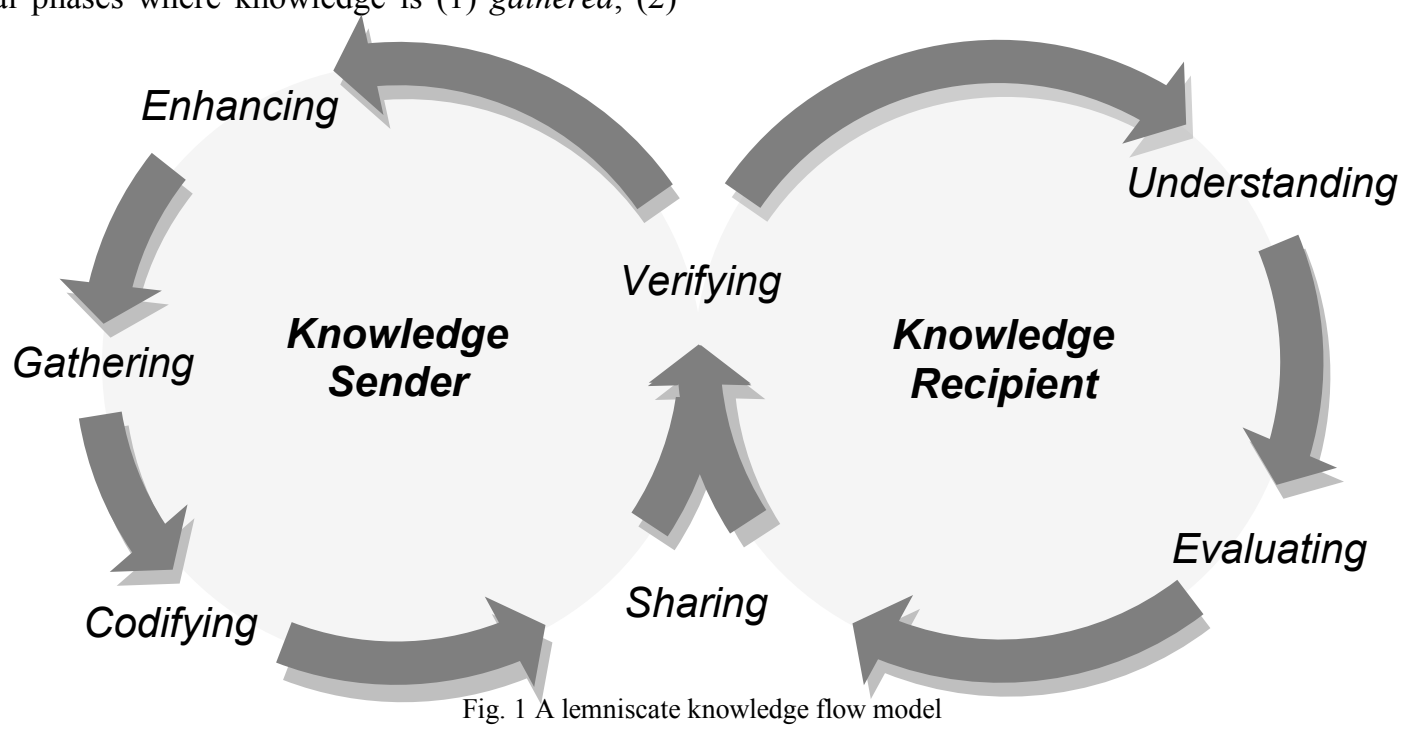

The knowledge sender gathers, processes and combines relevant resources at some point in time. If the composed resources of knowledge are complete and consistent for a given discourse of the universe, then they are codified (articulated), which in turn leads to the creation of the realworld meaning of concepts and relations explicitly and precisely. On the other hand, knowledge codification can be a source of value creation, "reused" either by the knowledge recipient or other knowledge creators. Undoubtedly, an efficient IT system plays a decisive role in the application of the codification strategy. Knowledge sharing is an activity that aims to exchange particular resources among the knowledge sender and their recipients. An efficient and useful technology should support contexts like localization and the knowledge form, hardware capabilities and requirements, language skills, on-the-fly content recommendation and the recipient's learning predisposition. Simultaneous verification of knowledge takes place during its exchange by both a sender and a recipient. The perception and understanding of knowledge incorporates cognitive processes, beliefs and human intelligence, as well as the tacit knowledge currently possessed by the involved individual. At the same time, the knowledge is evaluated, which means that each consistent part is checked to fulfil such criteria as reliability, applicability and significance [25]. Feedback given from a knowledge recipient may reveal some errors, inaccuracies or gaps in shared knowledge resources. On the other hand, which seems to be even more important, it may spontaneously trigger valuable expertise, up to that point deeply concealed in a recipient's mind. Such reactions might indicate and advocate possible changes, supplements or withdrawals of particular knowledge resources. In this case, knowledge refinement may lead to its higher quality, described by attributes such as adequacy, effectiveness and productiveness [26]. 
Generally speaking, in regard to knowledge "visibility", classically, knowledge resources are divided into two types: explicit or tacit [27], while the former by assumption is not cognitively biased. For this reason people naturally tend to share knowledge with others to evaluate its veracity, based on given feedback, and afterwards to consolidate and codify it. On the other hand, any body of knowledge might be codified to a certain extent, where skills and competence are hardly transferable.

\section{RESEARCH BACKGROUND}

Among the numerous tasks given to students to perform, were those where they needed to actively collaborate in separate groups in the classroom or at home, and exhibit the means and tools to exchange data, information and knowledge. In this manner, we provided the preliminary results of our observations and conducted short interviews, which, synthesised together, allowed us to formulate a set of facts, specified below. Obviously, the elementary means of close communication was oral dialogue or open discussion. However, a few members reported obstacles in effective group work, such as the "sucker effect", or intrapersonal factors (also recognized and described in [28]). At a distance, instant messaging tools over the Internet (e.g. Skype) were preferred to the phone. Group members used a variety of other software tools to explicit and codify gathered or possessed information. In peer-to-peer communication, Facebook Messenger was the most preferable tool. In the store-and-forward model, emails were sent occasionally to announce some general assumptions, share documents (via attached files) or one asked others to evaluate or accept changed settings.

\section{CONCLUSIONS}

The elaborated knowledge flow model (fig. 1) is an abstract view of the process of knowledge management. To our best belief, it seems to be complete (definite starting and ending points), computer-aided (various ICT are employed) and generic (not biased by any domain); the indicated sequential iterations, where the bi-directional, spoken or written exchange of observations takes place, demonstrate its unfolded nature.

"We have a conviction to learn during our whole life" this straightforward sentence reflects the nature of a human life in present times.

\section{REFERENCES}

[1] K. Marciniak, and M. L. Owoc, "Systemy klasy business intelligence w jednostkach sektora publicznego-wstępne studium badań," Studia Ekonomiczne, vol. 199, 2014, pp. 166-175.

[2] M. Hernes, "Using Cognitive Agents for Unstructured Knowledge Management in a Business Organization's Integrated Information System", Intelligent Information and Database Systems, Springer, Berlin 2016, pp. 344-353.
[3] G. Kayakutlu, and E. Laurent-Mercier, "From knowledge worker to knowledge cultivator-effective dynamics", IEEE 2012, pp. 11491153.

[4] M. Hernes, and A. Bytniewski, "Towards Big Management" [in:] Advanced Topics in Intelligent Information and Database Systems, Springer 2017, pp. 197-209.

[5] M. L. Owoc, and P. Weichbroth, "A Framework for Web Usage Mining Based on Multi-Agent and Expert System". AITM2011, Wrocław 2011, pp. 139-151.

[6] T. Sitek, and P. Weichbroth, "Ekonometryczne szacowanie parametrów jako metoda przetwarzania wstepnego $w$ systemach agentowych", PWNT, Gdańsk 2009, pp. 303-313.

[7] P. Weichbroth, and M. Owoc, "Wartościowanie wiedzy o ścieżkach nawigacji użytkowników portali internetowych", Technologie wiedzy w zarządzaniu publicznym. Wydawnictwo UE w Katowicach, Katowice 2014, pp. 326-337.

[8] M. Owoc, and P. Weichbroth, "Toward knowledge-grid model for academic purposes". AI4KM2015, Buenos Aires 2015, pp. 5-9.

[9] M. L. Owoc, and P. Weichbroth, "Transformacje wiedzy sieciowej. Podstawy ontologiczne". In: Wiedza w kreowaniu przedsiębiorczości, K. Perechuda, I. Chomiak-Orsa (Eds.), Wydawnictwo Politechniki Częstochowskiej, Częstochowa 2014. pp. 165-177.

[10] M. Owoc, and K. Marciniak, "Knowledge management as foundation of smart university", IEEE, 2013, pp.1267-1272.

[11] K. Marciniak, and M. L. Owoc, "Usability of Knowledge Grid in Smart City Concepts", ICEIS (3), 2013, pp. 341-346.

[12] K. Marciniak, and M. L. Owoc, "Applying of knowledge grid models in smart city concepts", Uniwersytet Ekonomiczny we Wrocławiu, Wrocław 2013, pp. 238-244.

[13] M. Alsqour, and M. L. Owoc, "Benefits of knowledge acquisition systems for management. An empirical study", IEEE, 2015, pp. 1691-1698.

[14] M. L. Owoc, "The Role of Data Warehouse as a Source of Knowledge Acquisition in Decision-Making. An Empirical Study". In: AI for Knowledge Management. Springer 2014, pp. 21-42.

[15] M. Alsqour, M. L. Owoc, and A. S. Ahmed, "Data warehouse as a source of knowledge acquisition. An empirical study", IEEE, 2014, pp. 1421-1430.

[16] P. Kapłański, and P. Weichbroth, "Cognitum Ontorion: Knowledge Representation and Reasoning System", IEEE 2015, pp. 169-176.

[17] A. Seganti, P. Kapłański, and P. Zarzycki, "Collaborative Editing of Ontologies Using Fluent Editor and Ontorion", Ontology Engineering, Springer, 2015, pp. 45-55.

[18] P. Kapłański, "Controlled English interface for knowledge bases", Studia Informatica, vol. 32(2A), 2011, pp. 485-494.

[19] M. H. Zack, "Rethinking the knowledge-based organization". MIT Sloan Management Review, vol. 44(4), 2003, pp. 67-72.

[20] P. Weichbroth, and M. L. Owoc, "Web User Navigation Patterns Discovery as Knowledge Validation challenge", AI4KM 2012, France 2012, pp. 33-39.

[21] E. Mercier-Laurent, J. Jakubczyc, and M. L. Owoc, "What is Knowledge Management?", Prace Naukowe Akademii Ekonomicznej we Wrocławiu, vol. 815, 1999, pp. 9-21.

[22] J. Fazlagić, M. Sikorski, and A. Sala, „Portale intranetowe. Zarządzanie wiedza, kapitat intelektualny, korzyści dla pracowników i dla organizacji”. Politechnika Gdańska, Gdańsk 2014.

[23] P. Dominiak, and K. Leja, „Czy uniwersytet potrzebuje strategii?”. CBPNiSW, Uniwersytet Warszawski, 2000, pp. 26-42.

[24] D. J. Teece, "Research directions for knowledge management. California management review, vol. 40(3), 1998, pp. 289-292.

[25] M. L. Owoc, M. Ochmanska, and T. Gladysz, "On principles of knowledge validation", Validation and Verification of Knowledge Based Systems, Springer, 1999, pp. 25-35.

[26] M. L. Owoc, "Wartościowanie wiedzy w inteligentnych systemach wspomagajacych zarzadzanie", Prace Naukowe Akademii Ekonomicznej we Wrocławiu. vol. 100 (1047), Wrocław 2004.

[27] N. Rizun, and Y. Taranenko, "Simulation models of human decisionmaking processes", Management Dynamics in the Knowledge Economy. College of Management, vol. 2(2), 2014, pp. 241-264.

[28] P Weichbroth, "Facing the Brainstorming Theory. A Case of Requirements Elicitation". Studia Ekonomiczne. Zeszyty Naukowe Uniwersytetu Ekonomicznego w Katowicach, 6 (296), pp. 151-162. 